\title{
Occurence of Caelifera larvae depending on zoogenic disturbances
}

\author{
Vorkommen von Larven der Kurzfühlerschrecken (Caelifera) \\ in Abhängigkeit von zoogenen Störstellen
}

\author{
Jörn Krütgen \\ Faunistisch-Ökologische Arbeitsgemeinschaft e.V., c/o Institut für Natur- und Ressourcenschutz der \\ Christian-Albrechts-Universität zu Kiel, Olshausenstraße 75,24118 Kiel, joern@foeag.de
}

\section{Schlüsselwörter:}

Kurzfühlerschrecken, Caelifera, Larven, zoogene Störstellen, wildlebende Huftiere

\section{Keywords:}

short-horned grasshopper, Caelifera, larvae, zoogenic disturbances, ungulates living in the wild

\begin{abstract}
Zusammenfassung
Mit Hilfe von Transekterfassungen wurde die Zahl an Caelifera-Larven auf 12 Probeflächen im Kreis Segeberg, Schleswig-Holstein ermittelt. Bei den Flächen handelte es sich um 7 junge, eingezäunte Aufforstungen, eine gleichaltrige, ungezäunte Aufforstung sowie 4 von wildlebenden Huftieren (insbes. Damhirsch) beäste Sukzessionsflächen. Während die den Huftieren zugänglichen Flächen regelmäßig Störstellen (Offenboden) durch Wühlen oder Vertritt aufwiesen, fehlten diese in den gezäunten Flächen fast vollständig. Störstellen gingen hier auf den Einsatz von Maschinen oder das Wirken von Kleinsäugern oder Ameisen zurück. Die vorliegenden Ergebnisse zeigen, dass auf den gezäunten Flächen deutlich weniger Larven gefunden werden konnten. Eine mögliche Erklärung hierfür ist der Mangel an Störstellen wodurch zum einen Reproduktionsstätten, zum anderen mikroklimatische Gunsträume für Caelifera-Larven fehlten.
\end{abstract}

\section{Abstract}

The amount of Caelifera-larvae was recorded by linear transect walks at 12 study sites in the district of Segeberg, Schleswig-Holstein. Of the 12 study sites, seven were young, fenced reforestations, one unfenced reforestation of similar age and four strongly browsed (fallow deer) succession sites. While on sites accessible to ungulates disturbances (open soil) due to burrowing or trampling occurred regularly, disturbances on fenced sites lacking almost completely. Here, disturbed areas could instead be traced back to the use of machines or to activities of small animals like rodents or ants. Results show that on fenced sites the amount of caught Caelifera larvae per transect was much lower than on browsed succession sites. A possible explanation could be the lack of areas with open soil on fenced sites, and therefore a lack of reproduction sites and preferred sites for larvae of Caeliferalarvae due to microclimatic conditions. 

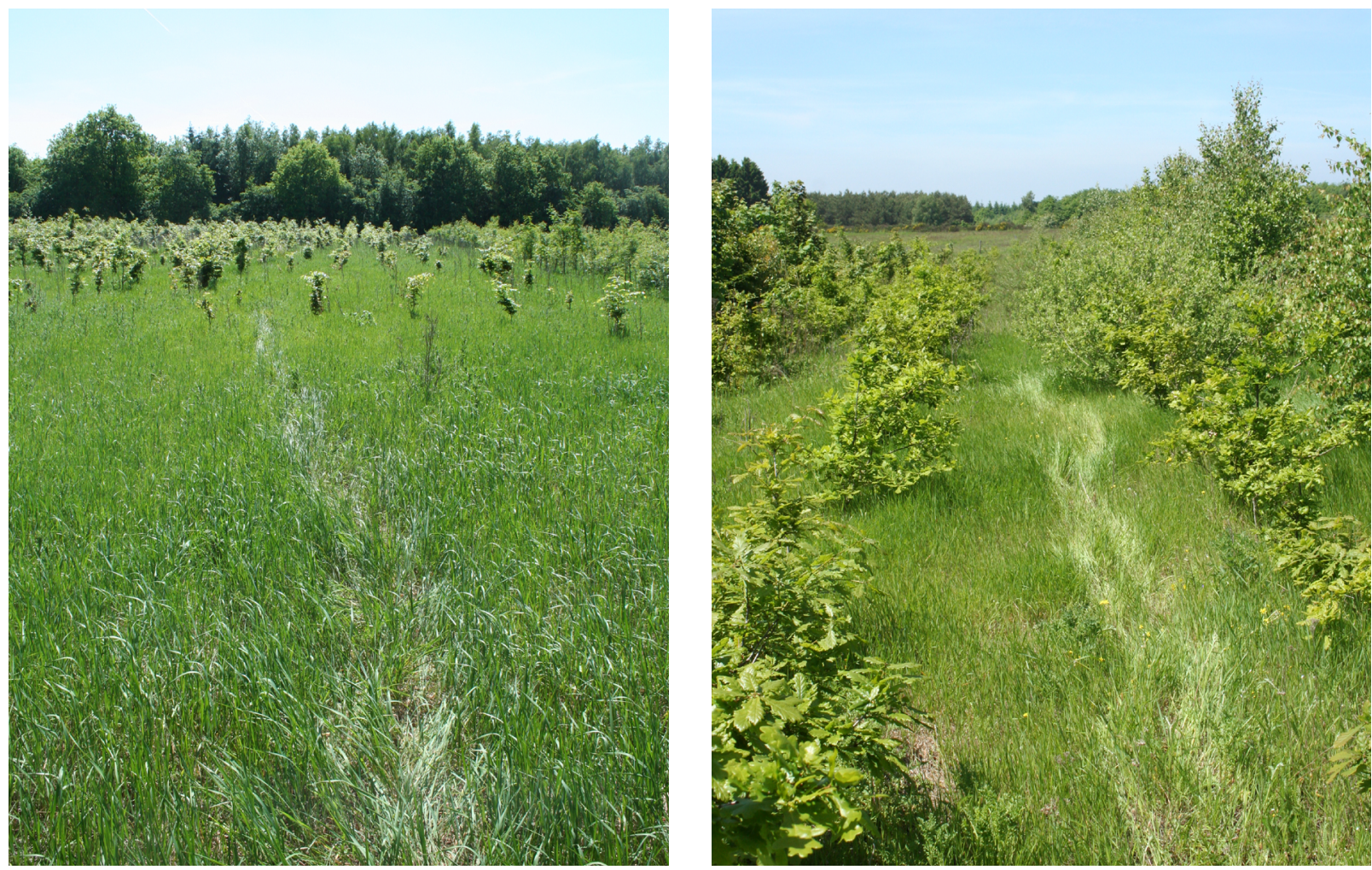

Figs. 1 \& 2: Transect examples, from left to right: fenced forestation near Trappenkamp (FFT), fenced forestation near Negernbötel (FFN).

\section{Introduction}

Commonly, the word 'disturbance' has a negative meaning. From the ecological point of view, however, the term is neutral and describes processes as components of the steady state of an ecosystem. Apart from profound alterations of a system caused by fire, storms or insect calamities, smaller disturbances occurring regularly which are variable in time and space play an important role in for the preservation of local species diversity. According to the Intermediate Disturbance Hypothesis (IDH) (Conell 1978) local diversity of species is highest at intermediate levels of disturbance, while local diversity is lower in undisturbed sites as well as at higher levels of disturbance. Species like ants, rodents as well as large herbivores (Thompson Hobbs 2006) can change their environments and create new structures such as spots of open soil, which might offer important functions for other organisms like grasshoppers as well (Reck 1993, Schulz 2003). Species which affect their environments permanently are considered ecosystem engineers (Jones 1994), while their effect on an ecosystem is termed a key-factor (Steward
2001). Goal of the project 'Game and Biodiversity' is to identify the effect of free ranging ungulates in ecosystems and to understand their importance for the habitat studying short-horned grasshoppers (Caelifera) (Reck et al. 2009). Investigations not only considered imagines (Krütgen 2012a), but also included studies of clutches or larvae. Here, however, we present results on the influence of zoogenic disturbance of sites (by free ranging ungulates) for the occurrence of Caelifera larvae in a cultural landscape.

\section{Methods}

\section{Research area}

The research area is located at the eastern border of the natural geographic region "Holsteinische Vorgeest". It is characterized by an open landscape with less than $20 \%$ of woodland and without high amounts of arable fields ( $>50 \%$ ) or grassland ( $>25 \%$ ) (BfN 2007). The moraine landscape originating from the Saalian glaciation was covered by glaciofluvial sand and gravel transported by the melting glaciers of the Weichselian 

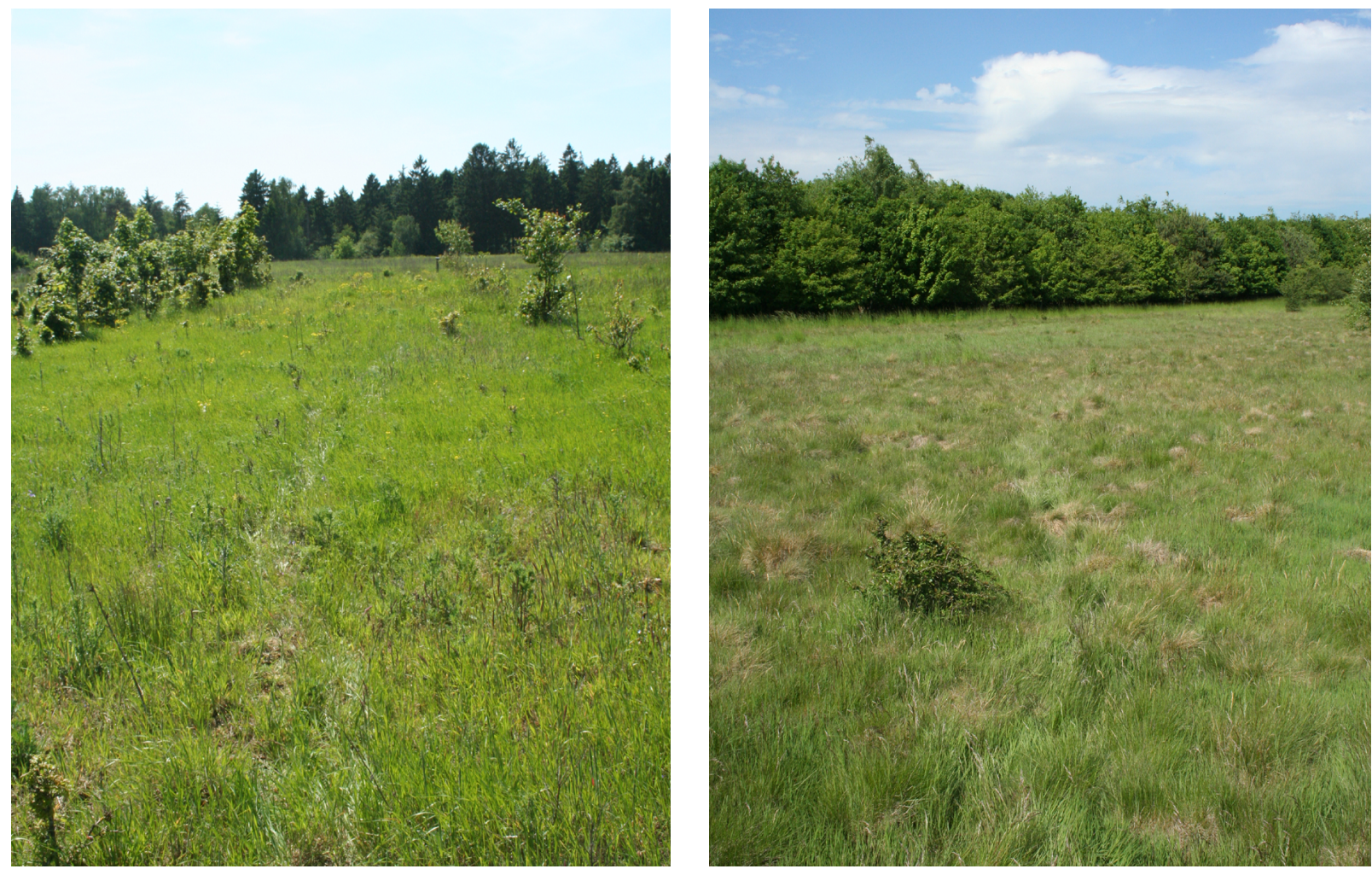

Figs. 3 \& 4: Transect examples, from left to right: unfenced forestation (UF), heavily browsed succession site (BSS4).

glaciation. Later mires, fens and inland dunes developed, of which nowadays only relics remain. Historically frequent dwarf shrub heathlands were either afforested with coniferous trees (e.g. Segeberger Forest) or used as arable fields after deep ploughing.

Today, agriculturally used area dominates the landscape with a recent shift to arable land. Woodlands are used for forestry (BfN 2012).

\section{Study sites}

In total, 12 sites were investigated. Of these, four were young fenced forestations, one an unfenced forestation of similar age and four heavily browsed succession sites in the vicinity of Negernbötel, district Segeberg. Additionally, three fenced forestations near Trappenkamp, district Segeberg, were studied (fig. 1-4).

The four fenced forestations near Negernbötel as well as the unfenced forestation and succession site 4 were located adjacent to each other. The other succession sites were located in a distance between 500 to $1500 \mathrm{~m}$. The three fenced forestations near Trappenkamp were about $4 \mathrm{~km}$ north of the study sites at Negernbötel.

All study sites were characterized by sandy, nutrient poor and non-cohesive soils.

\section{Grashopper fauna}

In the course of various monitoring or research programs, the grasshopper fauna in the vicinity of Negernbötel was investigated intensively since 2005 (Krütgen 2012b, Reck et al. 2009, Schulz et al. 2013, Winkler 2012, 2016). On the study sites and in their surroundings the short horned grasshopper species Chorthippus albomarginatus, Chorthippus apricarius, Chorthippus biguttulus, Chorthippus brunneus and Omocestus viridulus were found relatively frequent. Furthermore, Pseudochortippus parallelus, Myrmeleotettix maculatus as well as Tetrix undulata and Tetrix subulata were observed regularly, while Chorthippus mollis, Omocestus haemorrhoidalis and Stetophyma grossum occurred more rarely and Chorthippus montanus and Stenobothrus lineatus were found only once.

\section{Data collection and analysis}

On three successive days (June 4th - 6th 2010) with comparable weather conditions (base temperature $20^{\circ} \mathrm{C}$, cloud cover $<10 \%$, no precipitation, max. weak 
Tab. 1: Amount or larvae per transect and study site, mean, standarddeviation and median; transects: BSS heavily browsed succession site, UF: unfenced forestation, FF: fenced forestation, N: Negernbötel, T: Trappenkamp.

\begin{tabular}{|c|c|c|c|c|c|c|c|c|}
\hline Study site & $\begin{array}{c}\text { Accessed by } \\
\text { ungulates }\end{array}$ & 1 & $\begin{array}{c}\text { ansec } \\
2\end{array}$ & 3 & total & mean & $\begin{array}{l}\text { Standard } \\
\text { deviation }\end{array}$ & median \\
\hline BSS1 & + & 58 & 64 & 34 & 156 & 52 & 15,87 & 58 \\
\hline BSS2 & + & 15 & 14 & 30 & 59 & 19,67 & 8,96 & 15 \\
\hline BSS3 & + & 21 & 16 & 108 & 145 & 48,33 & 51,73 & 21 \\
\hline BSS4 & + & 6 & 32 & 16 & 54 & 18 & 13,11 & 16 \\
\hline total BSS & + & 101 & 128 & 191 & 414 & 34,5 & 29,13 & 25,5 \\
\hline UF & + & 13 & 26 & 39 & 78 & 26 & 13 & 26 \\
\hline FFN1 & - & 7 & 10 & 15 & 32 & 10,67 & 4,04 & 10 \\
\hline FFN2 & - & 25 & 12 & 23 & 60 & 20 & 7 & 23 \\
\hline FFN3 & - & 16 & 6 & 9 & 31 & 10,33 & 5,13 & 9 \\
\hline FFN4 & - & 9 & 0 & 5 & 14 & 4,67 & 4,51 & 5 \\
\hline total FFN & - & 57 & 28 & 52 & 137 & 11,42 & 7,3 & 9,5 \\
\hline FFT1 & - & 3 & 7 & 13 & 23 & 7,67 & 5,03 & 7 \\
\hline FFT2 & - & 3 & 10 & 16 & 29 & 9,67 & 6,51 & 10 \\
\hline FFT3 & - & 20 & 22 & 28 & 70 & 23,33 & 4,16 & 22 \\
\hline total FFT & - & 26 & 39 & 57 & 122 & 13,56 & 8,71 & 13 \\
\hline
\end{tabular}

Tab. 2: Mann-Whitney pairwise comparisions: above: uncorrected p-values, underneath: Bonferroni corrected p-values.

\begin{tabular}{llcl} 
& BSS & FFN & FFT \\
\hline Heavily browsed succession site (BSS) & & 0,006022 & 0,03574 \\
\hline Fenced forestation Negernbötel (FFN) & 0,01807 & 0,6183 \\
\hline Fenced forestation Trappenkamp (FFT) & 0,1072 & 1 & \\
\end{tabular}

wind) the number of Caelifera larvae was recorded in 36 transects. Data was sampled in three days at approximately the same daytime (forenoon till afternoon) to ensure comparability of results. Each transect was recorded for ten minutes. Transects were sampled in a width of $50 \mathrm{~cm}$ each. To avoid a negative influence due to shadowing by young trees, transects in the forestations were only chosen in open and sunny sections.
The research focused on young states of Caelifera larvae, because especially these should benefit from dry and warm microclimatic conditions (Ingrisch \& Köhler 1998, Wünsch et al. 2010).

For statistical analysis data was grouped into two categories. On the one hand the browsed succession sites accessed by wild living ungulates $(+)$ and on the other hand the fenced forestations without access 
to wild living ungulates (-). In the latter case, samples were further grouped according to study sites near Negernbötel (FFN) and those near Trappenkamp (FFT). The unfenced forestation was not taken into consideration because it is a mixture of both classifications and there is insufficient data for an own class. Its interpretation is purely descriptive.

Groups of sites (BSS, FFN \& FFT) were compared by the number of Caelifera larvae per transect.

Since numerical data are typically not normally distributed, a Kruskall-Wallis-median-test was used (Wheater et al. 2011).

In addition, a Mann-Whitney-median-test was used for single pair comparisons of fenced versus unfenced sites.

The analyses were done using the statistic program PAST (Hammer 2012).

\section{Results}

Highest mean number of larvae per transect were found on browsed succession sites (Tab.1), with three times as many larvae found on browsed succession sites than on fenced forestation sites. The total amount of larvae at the unfenced forestation was also above all fenced sites. The standard deviation was higher at the browsed succession sites. The lowest standard deviation was recorded at fenced forestations.

Table 1 shows the amount of Caelifera larvae per transect and study site. In addition the arithmetic mean, standard deviation and median of the study sites are given. The three groups of studied sites differed significantly in the mean number of larvae found per transect (Kruskall-Wallis-median-test: H: 8,769 Hc: 8,793, $\mathrm{p}$ (same): 0,01247). The number of larvae found at fenced forestation sites at Negernbötel (FFN) differed significantly from the number found at heavily browsed succession sites (BSS) (padj. $<0,02$ ). No significant differences were found between the number of larvae found at FFN and FFT (padj.=1) or BSS and FFT (padj. $=0,1072$ ).

On heavily browsed succession sites significantly more Caelifera larvae per transect were found than on fenced forestation sites (Mann-Whitney $\mathrm{U}: 48$; p(same): 0,003681).

The three groups of studied sites differed significantly in the mean number of larvae found per transect (Kruskall-Wallis-median-test: H: 8,769 Hc: 8,793, p(same):
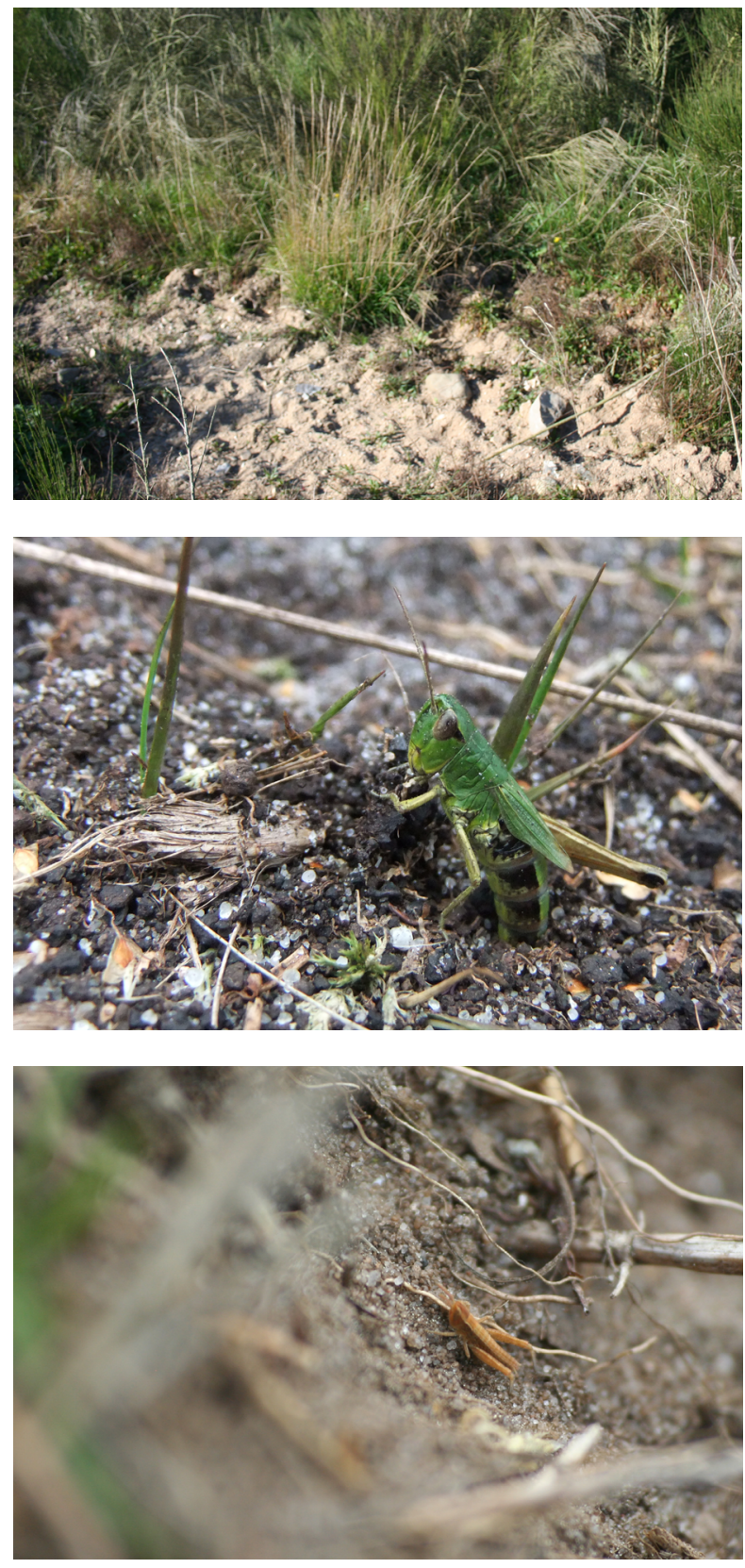

Figs. 5-7: Spot of open soil due to trampling, oviposition of Pseudochorthippus parallelus parallelus, Caelifera larvae on a zoogenic disturbed site.

0,01247). The number of larvae found at fenced forestation sites at Negernbötel (FFN) differed significantly from the number found at heavily browsed succession sites (BSS) (padj. < 0,02). No significant differences were found between the number of larvae found at FFN and FFT (padj. =1) or BSS and FFT (padj. = 0,1072).

On heavily browsed succession sites significantly more Caelifera larvae per transect were found than on fenced forestation sites (Mann-Whitney U: 48; p(same): 0,003681). 


\section{Discussion}

Differences in the number of Caelifera larvae found on study sites can be explained by differences in the amount of areas with open soil (Schulz 2003). Wünsch et al. (2010) found young larvae of Myrmeleotettix maculatus especially in warm microhabitats with reduced vegetation cover. Warm surroundings are considered to benefit the development of larvae (Ingrisch \& Köhler 1998, Willott \& Hassal 1998). Oschmann (1973) and Cherill \& Brown (1992) suggest that the occurrence of young larvae can indicate the location of oviposition sites.

It can be assumed that beneficial effects of a warm microclimate are especially important for various shorthorned grasshopper occurring in poor and dry habitats. Areas of open soil are considered important reproduction sites for most of the species occurring on the study sites. $70 \%$ of all species, recorded in the study area, use soil for oviposition (Ingrisch \& Köhler 1998). Therefore, if patches of open soil, where young larvae were found, existed already in the year prior to the study, these were most likely used for oviposition and larvae hatched here. On fenced forestation sites, disturbances only occurred due to anthropogenic use of machines and were commonly older and heavily overgrown. Patches of open soil caused by zoogenic disturbance were common only in the browsed succession sites, without a regular distribution pattern. The irregular distribution of patches of bare soil explains the partially high standard deviation on these study sites. The number of larvae found per transect therefore highly depends on the proportion of open soil. On fenced forestation sites, where fewer disturbances were recorded, fewer larvae were found (except for FFN2 and FFT3), but the distribution of larvae along the transects was more regular, resulting in a lower standard deviation. An explanation for this could be the more regular distribution of disturbed patches due to anthropogenic influences (machines) and the general lack of suitable reproduction sites.

Schulz (2003) suggests that in areas with dense vegetation cover the ovopoition sites are rare and clutches arise cumulatively.

The results show that the exclusion of free ranging ungulates may lead to a loss of suitable habitats for Caelifera. The suitability depends on the lack of favorable microhabitats for larvae as well as suitable reproduction sites. The amount of larvae on the unfenced forestation shows that this happens before the pioneer forests generally lose their habitat suitability due to shadowing.

\section{Acknowledgments}

The investigations at the Institute for Natural Resource Conservation of Kiel University are promoted by the foundation natur + mensch. I would like to thank Dr. Heinrich Reck, Schwentinental, and Dr. Corinna Rickert, Leipzig, for their advices concerning the manuscript, Dr. Corinna Rickert, Leipzig, also supported the translation.

\section{Author}

\section{Jörn Krütgen}

Jörn Krütgen studied geography with zoological and landscape-ecological specialization. He works for the federal Nature Conservation Department of Schleswig-Holstein, Germany. The main topic of his work is faunistic species protection. Field herpetology is a focus of his education and work. Snakes and their protection are of particular interest.

\section{References}

BFN - Bundesamt für Naturschutz (2007) Landschaftstypen, http://www bfn.de/0311_landschaftstypen.html, last accessed August 26, 2021.

BFN - Bundesamt für Naturschutz (2012) Landschaftsteckbrief - 69801 Holsteinische Vorgeest, https://www.bfn.de/landschaften/steckbriefe/ landschaft/show/69801.html, last accessed October 15, 2021.

Cherrill AJ, Brown VK (1992) Ontogenetic changes in the micro-habitat preferences of Decticus verrucivorus (Orthoptera: Tettigoniidae) at the edge of its range. Ecography 15:37-44.

Connel JH (1978) Diversity in Tropical Rain Forests and Coral Reefs. Science 199:1302-1310.

Hammer M (2012) PAST PAleontological STatistics Version 2.17 Reference manual, http://priede.bf.lu.lv/ftp/pub/TIS/datu_analiize/ PAST/2.17c/pastmanual.pdf, last accessed October 15, 2021

Ingrisch S, Köhler G (1998) Die Heuschrecken Mitteleuropas. Westarp Wissenschaften, Magdeburg.

Jones CJ, Lawton JH, Shachak M(1994) Organisms as ecosystem engineers. Oikos 69:373-386.

Krütgen J (2012a) Die Bedeutung wildlebender Huftiere für das Vorkommen von Kurzfühlerschrecken (Caelifera) am Beispiel der Gefleckten Keulenschrecke (Myrmeleotettix maculatus) und der Säbeldornschrecke (Tetrix subulata). Articulata 27(1/2):67-77.

Krütgen J (2012b) Erfassung der Heuschrecken in den Holsteiner Lebensraumkorridoren - Jahresbericht 2012. Unveröffentlichtes Gutachten im Auftrag des Instituts für Natur- und Ressourcenschutz der ChristianAlbrechts-Universität zu Kiel.

Oschmann M (1973) Untersuchungen zur Biotopbindung der Orthopteren. Faunistische Abhandlungen 4(21)177-206.

Reck H (1993) Haben Tierbauten eine Bedeutung als Habitatbaustein für den Feldgrashüpfer (Chorthippus apricarius L. 1758)? Articulata 8(1):45-51. 
Reck H, Dolnik C, Winkler C, Krütgen J, Breuer V, Graumann S, Groth J, Schreiner R (2009) Monitoring zur bioökologischen Wirksamkeit der Grünbrücke Kiebitzholm, Untersuchungszeitraum 2007-2008. Unveröffentlichter Bericht. Ökologiezentrum der Christian-AlbrechtsUniversität zu Kiel.

Schulz B (2003) Zur Bedeutung von Beweidung und Störstellen für Tierarten am Beispiel der Verteilung von Feldheuschreckengelegen im Grünland. Articulata 18(2/2):151-178.

Schulz B, Müller K, Nissen, H (2013) Umfeldgestaltung und Hinterlandanbindung von Querungshilfen am Beispiel des E+E-Vorhabens "Holsteiner Lebensraumkorridore". Natur und Landschaft 88:509-515.

Steward AJA (2001) The impact of deer on lowland woodland invertebrates: a review of the evidence and priorities for future research. Forestry $74(3): 259-270$.

Thompson Hobbs $N$ (2006) Large herbivores as sources of disturbance in ecosystems. In: Danell K, Bergström R, Duncan P, Pastor J (eds) Large Herbivore Ecology, Ecosystem Dynamics and Conservation. Cambridge University Press, Cambridge, pp 261-288.

Townsend CR, Harper JL, Begon ME (2002) Ökologie. Springer-Verlag, Berlin, Heidelberg, New York.

Wheater CP, Bell JR, Cook PA (2011) Practical Field Ecology: A Project Guide. Wiley-Blackwell, West Sussex.

Willott SJ, Hassall M (1998) Life-history responses of British grasshoppers (Orthoptera: Acrididae) to temperature change. Funct. Ecol.12:232-241.

Winkler C (2012) Erfassung der Heuschrecken in den Holsteiner Lebensraumkorridoren - Jahresbericht 2011. Unveröffentlichtes Gutachten im Auftrag des Instituts für Natur- und Ressourcenschutz der Christian-AlbrechtsUniversität zu Kiel.

Winkler C (2016) Zur Bedeutung der Grünbrücke Kiebitzholm für Heuschrecken. Faun. Ökol. Mitt. 9:443-442.

Wünsch Y, Schirmel J, Fartmann T (2010) Habitatnutzung juveniler Myrmeleotettix maculatus (Caelifera: Gomphocerinae) und Platycleis albopunctata (Ensifera: Tettigoniinae) in Küstendünen. Articulata 25(2):167-183.

\section{Open Access}

>> This article is published under the Creative Commons Attribution 4.0 International license (https://creativecommons.org/licenses/by/4.0/ deed.en). Please note that individual, appropriately marked parts of the article may be excluded from the license mentioned or may be subject to other copyright conditions. If such third party material is not under the Creative Commons license, any copying, editing or public reproduction is only permitted with the prior consent of the respective copyright owner or on the basis of relevant legal authorization regulations. 